\title{
Use of the kidney injury molecule-1 as a biomarker for early detection of renal tubular dysfunction in a population chronically exposed to cadmium in the environment
}

\author{
Werawan Ruangyuttikarn', Amnart Panyamoon ${ }^{1}$, Kowit Nambunmee ${ }^{2}$, Ryumon Honda ${ }^{3}$, \\ Witaya Swaddiwudhipong ${ }^{4}$ and Muneko Nishijo $5^{5^{*}}$
}

\begin{abstract}
Cadmium (Cd) has been found as an environmental pollutant in Mae Sot district, Tak province, Thailand. Prolong exposure to high levels of $\mathrm{Cd}$ of the resident increases high risk of $\mathrm{Cd}$ toxicity especially to kidney which is the primary target of $\mathrm{Cd}$. In order to investigate the early effect of $\mathrm{Cd}$ induced renal dysfunction, a kidney injury molecule-1 (KIM-1), a novel biomarker of renal tubular dysfunction, was measured using an enzyme linked immunosorbent assay (ELISA). The method was validated and used to quantify the KIM-1 concentrations in the urine of 700 subjects (260 men, 440 women) who lived in the Cd contaminated area. The KIM-1 concentrations were compared to the concentrations of two conventional renal tubular dysfunction biomarkers, $\mathrm{N}$-acetyl- $\beta$-Dglucosaminidase (NAG) and $\beta_{2}$-microglobulin $\left(\beta_{2}-\mathrm{MG}\right)$. Urinary KIM-1 was correlated with urinary and blood $\mathrm{Cd}$ as well as NAG. After adjustment of age and smoking, urinary KIM-1 was correlated with blood $\mathrm{Cd}$ more than urinary NAG did. Clear dose response relationships of urinary KIM-1 with urinary $\mathrm{Cd}$ were shown in both men and women. These results indicate that the urinary KIM-1 might be more sensitive biomarker than urinary NAG and $\beta_{2}-M G$ for an early detection of renal tubular dysfunction. It is useful as a tool to detect renal effect of toxicity due to chronic $\mathrm{Cd}$ exposure at high level.
\end{abstract}

Keywords: KIM-1; Biomarker; Cadmium; Chronic exposure; Renal tubular dysfunction

\section{Introduction}

KIM-1 is a type 1 cell membrane glycoprotein containing six-cysteine immunoglobulin-like and mucin domains (Ichimura et al. 1998). It has been reported as an undetectable biomarker in normal urine but after kidney injury is expressed at high levels (Ichimura et al. 2004; Vaidya et al. 2008; Ferguson et al. 2008). Elevated KIM-1 level was also found in human renal diseases associated with renal fibrosis, inflammation and dysfunction (van Timmeren et al. 2007). It was proposed as an early indicator of acute kidney injury over the conventional biomarker such as blood urea nitrogen, serum creatinine $(\mathrm{Cr})$, urinary albumin, low molecular weight excreted

\footnotetext{
* Correspondence: ni-koei@kanazawa-med.ac.jp

${ }^{5}$ Department of Public Health, Kanazawa Medical University, Uchinada,

Ishikawa, Japan

Full list of author information is available at the end of the article
}

proteins $\left(\alpha_{1}\right.$ - and $\beta_{2}$-microglobulins (MG)) and tubular enzymes N-acetyl- $\beta$-D-glucosaminidase (NAG) (Han et al. 2002; Vaidya et al. 2006, Bonventre 2009, Hoffmann et al. 2010). It was also proposed as a novel urinary biomarker of cadmium induced nephrotoxicity via experimented rats and suggested that it could be indicated as a renal biomarker that is more sensitive and accurate than the other biomarkers (Vaidya et al. 2006; Prozialect et al. 2009). However, there is very limited report of KIM-1 study in human population exposed to cadmium $(\mathrm{Cd})$ except the study of association between KIM-1 and urinary Cd in elderly with low-dose Cd exposure (Pennemans et al. 2011).

$\mathrm{Cd}$ is an important industrial and environmental pollutant that adversely affects multiple organ systems (WHO 1992; Jarup et al. 1998), of which the kidney is the primary target in humans with chronic Cd exposure (Friberg 1984; Lauwerys et al. 1984; Jarup et al. 1998). 
Impairment in renal tubular function, generalized osteomalacia and osteoporosis with the resultant multiple bone fractures are predominant clinical signs of the Itaiitai disease. Itai-itai disease was the most severe manifestation of cadmium toxicity in patients documented in Japan who suffered chronic exposure to high cadmium concentrations in contaminated water and rice (Nogawa et al. 1987; Aoshima et al. 1988).

In Thailand, elevated levels of $\mathrm{Cd}$ in paddy soils and rice grain downstream of a zinc mineralized area in Mae Sot district, Tak province was reported in 2005 (Simmons et al. 2005). The Mae Sot district is located in a mountainous area on the Thai-Myanmar border, and it was famous for excellent rice that won national awards for many years. The contamination of $\mathrm{Cd}$ in rice is associated with suspended sediment transported to fields via the irrigation supply. Over $90 \%$ of the rice grain samples collected contained Cd at concentrations exceeding the Codex Committee on Food Additives and Contaminants (CCFAC) draft Maximum Permissible Level for rice grain of $0.2 \mathrm{mg} / \mathrm{kg}$. This poses a significant public health risk to local communities.

Prolonged consumption of the contaminated rice is believed to be a major source of $\mathrm{Cd}$ accumulation in the Mae Sot district residents. Our recent studies demonstrated that Mae Sot people have high risk of kidney damage with significantly high urinary $\mathrm{Cd}$ and high levels of renal dysfunction biomarkers such as $\alpha_{1}$ - and $\beta_{2}$-microglobulins $\left(\alpha_{1}-\mathrm{MG}, \beta_{2}-\mathrm{MG}\right)$ and $\mathrm{N}$-acetyl- $\beta$-Dglucosaminidase (NAG) (Swaddiwudhipong et al. 2007; Teeyakasem et al. 2007; Honda et al. 2010). The residents also have high levels of $\mathrm{Cd}$-associated chronic diseases such as hypertension, diabetes, osteoporosis and anemia (Swaddiwudhipong et al. 2010; Nambunmee et al. 2010, 2011). Swaddiwudhipong et al. (2012) recently reported a five year study (2005-2010) of the residents with prolonged exposure to high levels of environmental Cd, showing toxic effects may persist long after $\mathrm{Cd}$ exposure is reduced.

Therefore, a sensitive, specific and economical method for early detection of renal dysfunction induced by $\mathrm{Cd}$ is needed for health monitoring of the population, in whom signs and symptoms of acute kidney injury may not yet be manifested. We report here a use of the KIM-1 as a sensitive biomarker for early detection of renal tubular dysfunction in Mae Sot residents with high Cd exposure and compared its prevalence with those of two conventional renal biomarkers, NAG and $\beta_{2}$-MG concentrations to show usefulness of KIM-1 measurement among Cd exposed population at high level.

\section{Materials and methods Study population}

Seven hundred residents permanently living in the $\mathrm{Cd}$ contaminated area in 12 villages in Mae Sot district, were recruited to this study. They were comprised of 260 men and 440 women aged between 21-89 years. They had been selected non-randomly from among those found in a 2004-2005 survey (Swaddiwudhipong et al. 2007) with high urinary $\mathrm{Cd}$ levels greater than $5 \mu \mathrm{g} / \mathrm{g} \mathrm{Cr}$. All subjects were advised of the aim and methods of the project and consented to provide morning urine sample, $5-10 \mathrm{ml}$ of venipuncture blood, and demographic and health information. The study was approved by the Research Ethics Committee of the Faculty of Medicine, Chiang Mai University (Protocol approval No. 010/2009).

\section{Collection of urine and blood samples}

The morning urine samples were collected in a polyethylene bottle after the subjects underwent physical examination and anthropometric measurements. Qualitative tests for $\mathrm{pH}$, protein, glucose, occult blood, urobilinogen and ketone body were conducted on urine samples at the sampling site using paper strips (Ames test, Bayer, Germany). Each urine sample was divided into three aliquots of which any with $\mathrm{pH}<5$ one aliquot was adjusted to the $\mathrm{pH} 6-8$ by $0.5 \mathrm{~N}$ sodium hydroxide to prevent degradation of $\beta 2$-MG in acidic urine. Venous blood was collected from each subject in an EDTA vacutainer. All samples were kept at $-20^{\circ} \mathrm{C}$ before analysis.

\section{Determination of blood $\mathrm{Cd}$ and urinary $\mathrm{Cd}$ and creatinine}

Blood and urinary $\mathrm{Cd}$ concentrations were quantified using a flameless atomic-absorption spectrometer (Shimadzu Model AAS-6300, Japan). The urine was diluted by $20 \mathrm{mg} / \mathrm{l}$ palladium chloride solution in $5 \% \mathrm{HNO}_{3}$ as a matrix modifier at the ratio of 1:1. Proteins in blood were precipitated by $5 \% \mathrm{HNO}_{3}$ at the ratio of 1:2 (Honda 2010). Method validation of the technique were performed and verified by certified standard reference materials [urine reference material Lot No. 2670 (National Bureau of Standards, Washington D.C.) and control blood Lot No. 620302 (Behring Institute, Dresden, Germany)], to ascertain the accuracy and precision of the method. Detection limits of urinary and blood Cd were $0.06 \mu \mathrm{g} / \mathrm{g} \mathrm{Cr}$ and $0.2 \mu \mathrm{g} / \mathrm{l}$, respectively. The urinary $\mathrm{Cd}$ concentrations of each subjects were adjusted by each urinary creatinine concentrations measured by the enzyme assay (Cica liquid-S, Kantokagaku Reagent Division, Ltd., Japan).

\section{Determination of urinary renal markers}

The NAG level was quantified by a colorimetric assay using an NAG test kit (Shionogi Pharmaceuticals, Japan). The $\beta 2$-MG level was quantified by an enzyme immunoassay (GLAZYME $\beta 2$-microglobulin-EIA test kit, Sanyo Chemical Industries Ltd., Japan). Concentrations of both urinary NAG and $\beta_{2}$-MG were also adjusted per $\mathrm{g} \mathrm{Cr}$. 
The urinary KIM-1 was quantified by an in-house enzyme linked immunoassay (ELISA) using human KIM-1 standard, mouse anti-human KIM-1 antibody and horse radish peroxidase conjugated mouse anti-human KIM-1 antibody which were purchased from R\&D system, Minneapolis, MN, USA. The technique of ELIZA development was validated according to a bioanalytical recommendation (FDA 2001; DeSilva et al. 2003). The detection limit of urinary KIM-1 was $32.2 \mathrm{pg} / \mathrm{ml}$ and the limit of quantification was $110.7 \mathrm{pg} / \mathrm{ml}$. The detail process of preparation and validation of our KIM-1 assay was reported in somewhere (Panyamoon et al. 2009).

\section{Statistical analysis}

Data analysis was performed using the SPSS statistical package (Version 11.5). Logarithmic transformation was applied to $\mathrm{Cd}$ concentrations in urine and blood and all renal markers to achieve a normal distribution before being subjected to data analysis. Correlations between Cd exposure markers and KIM-1 concentrations were assessed by Spearman's rho analysis. Partial correlation analysis between $\mathrm{Cd}$ exposure and renal markers were performed after controlling for age and/or smoking habit at present. Comparisons of $\mathrm{Cd}$ exposure among groups at different smoking status and levels of renal markers among groups at different urinary $\mathrm{Cd}$ levels were analyzed by one-way ANOVA. Dose-response relationship between urinary $\mathrm{Cd}$ and KIM-1-uria was analyzed by probit regression model. At this time, KIM-1-uria was determined using cut-off value which was the 95 percentile values of urinary KIM-1 in the subjects with urinary $\mathrm{Cd}<2 \mu \mathrm{g} / \mathrm{g} \mathrm{Cr}$ (defined as non-exposure level of the urinary $\mathrm{Cd}$ by WHO). The P values of 0.05 or less were considered to identify statistical significance.

\section{Results}

\section{Characteristics of the subjects and qualitative screening} results

There were no different between genders of the average age, weight, height, body mass index and duration of residence in the area of the subjects in this study (Table 1). The mean age of the subjects was 54 years old and they all live permanently in the contaminated area for approximately 53 years (Table 1). Four hundred and twenty one subjects $(61 \%)$ out of 700 (159 men and 262 women) were older than 50 . Although all subjects had no severe clinical symptoms, the on-site screening examination with urinary strips showed 392 people had positive urinary protein, 326 subjects had positive blood, 2 subjects were found with positive urinary ketone and glucose and 105 subjects had urinary $\mathrm{pH}$ equal to 5 or lower. In addition, no participants had occupational exposure to $\mathrm{Cd}$.
Table 1 Characteristics of the subjects and concentrations of cadmium and renal markers

\begin{tabular}{llll}
\hline Variables & $\begin{array}{l}\text { Men } \\
(\mathbf{N}=\mathbf{2 6 0})\end{array}$ & $\begin{array}{l}\text { Women } \\
\mathbf{( N = 4 4 0 )}\end{array}$ & $\begin{array}{l}\text { Total } \\
\mathbf{( N = 7 0 0 )}\end{array}$ \\
\hline Age (years) & $55.6 \pm 14.0$ & $53.1 \pm 12.7$ & $54.0 \pm 13.2$ \\
\hline Weight $(\mathrm{kg})$ & $54.7 \pm 10.0$ & $51.3 \pm 10.6$ & $52.6 \pm 10.5$ \\
\hline Height $(\mathrm{cm})$ & $160.7 \pm 5.9$ & $151.1 \pm 5.1$ & $154.6 \pm 7.1$ \\
\hline BMl $\left(\mathrm{kg} / \mathrm{m}^{2}\right)$ & $21.1 \pm 3.1$ & $22.5 \pm 4.2$ & $22.0 \pm 3.1$ \\
\hline Duration of residence (years) & $54.1 \pm 15.0$ & $52.5 \pm 13.3$ & $53.1 \pm 14.0$ \\
\hline Never smoked $(\mathrm{N})$ & $16(6.2 \%)$ & $216(49.1 \%)$ & $232(33.1 \%)$ \\
\hline Ex-smokers $(\mathrm{N})$ & $86(33.1 \%)$ & $118(26.8 \%)$ & $204(29.1 \%)$ \\
\hline Occasional smokers $(\mathrm{N})$ & $19(7.3 \%)$ & $20(4.5 \%)$ & $39(5.6 \%)$ \\
\hline Regular smokers $(\mathrm{N})$ & $139(53.4 \%)$ & $86(19.6 \%)$ & $225(32.2 \%)$ \\
\hline Blood cadmium $(\mu \mathrm{gg} / \mathrm{L})$ & $6.7(1.0)$ & $4.9(2.0)$ & $5.5(2.0)$ \\
\hline Urinary cadmium $(\mu \mathrm{g} / \mathrm{gCr})$ & $6.3(1.8)$ & $7.0(1.9)$ & $6.7(1.9)$ \\
\hline KIM-1 $(\mathrm{pg} / \mathrm{g} \mathrm{Cr})$ & $860(2.3)$ & $1050(2.2)$ & $974.8(2.3)$ \\
\hline NAG $(\mathrm{U} / \mathrm{gCr})$ & $5.3(1.9)$ & $5.7(1.9)$ & $5.5(1.9)$ \\
\hline B2-MG $(\mu \mathrm{g} / \mathrm{gCr})$ & $367(9.5)$ & $184(6.1)$ & $237.9(7.5)$ \\
\hline $\mathrm{N}$ ) &
\end{tabular}

$\mathrm{N}$ : number of subjects; BMl: body mass index; $\mu \mathrm{g} / \mathrm{L}$ : microgram per liter; $\mu \mathrm{g} / \mathrm{gCr}$ : microgram per gram creatinine; $\mathrm{pg} / \mathrm{gCr}$ : picogram per gram creatinine; U/gCr: unit per gram creatinine; KIM-1: Kidney injury molecule-1; NAG: $N$-acetyl- $\beta$-D-glucosaminidase; $\beta 2-M G$ : $\beta_{2}$ microglobulin; values of cadmium and renal markers represent geometrical mean (geometrical standard deviation).

There were 232 subjects (33.1\%) who had never smoked with lower rate found in men $(6.2 \%)$ than in women (49.1\%) and number of men with regular smoking (53.4\%) were more than the number of regular smoking women (19.6\%) (Table 1). The geometrical means of Cd in both urine and blood were also shown in Table 1 with no genders difference. Figure 1 showed scatter plot of blood $\mathrm{Cd}$ and urinary $\mathrm{Cd}$ with high correlation between them $(\mathrm{r}=0.666, \mathrm{P}<0.001)$.

\section{Exposure markers, smoking status and renal dysfunction markers}

Only blood Cd concentrations in smoking status were significantly different from those Cd levels in never smoked subjects in both men and women (Table 2). There was no age difference of urinary cadmium in both genders, however, blood $\mathrm{Cd}$ in aged group $\geq 50$ years were significantly higher than those levels in the younger $(\mathrm{P}<0.001$, data not shown).

Scatter plots between log transformed urinary KIM-1, NAG and $32-$ MG and urinary Cd were shown in Figure 2. All of the renal markers were highly correlated to $\mathrm{Cd}$ exposure $(\mathrm{P}<0.001)$. Then, unadjusted and adjusted correlations by age and smoking status between blood $\mathrm{Cd}$ and renal markers were performed because of significant relationship of blood $\mathrm{Cd}$ and smoking status, and their correlation coefficients were shown in Table 3. Urinary Cd was analyzed with simple and partial correlations after controlling age in comparison to renal markers 


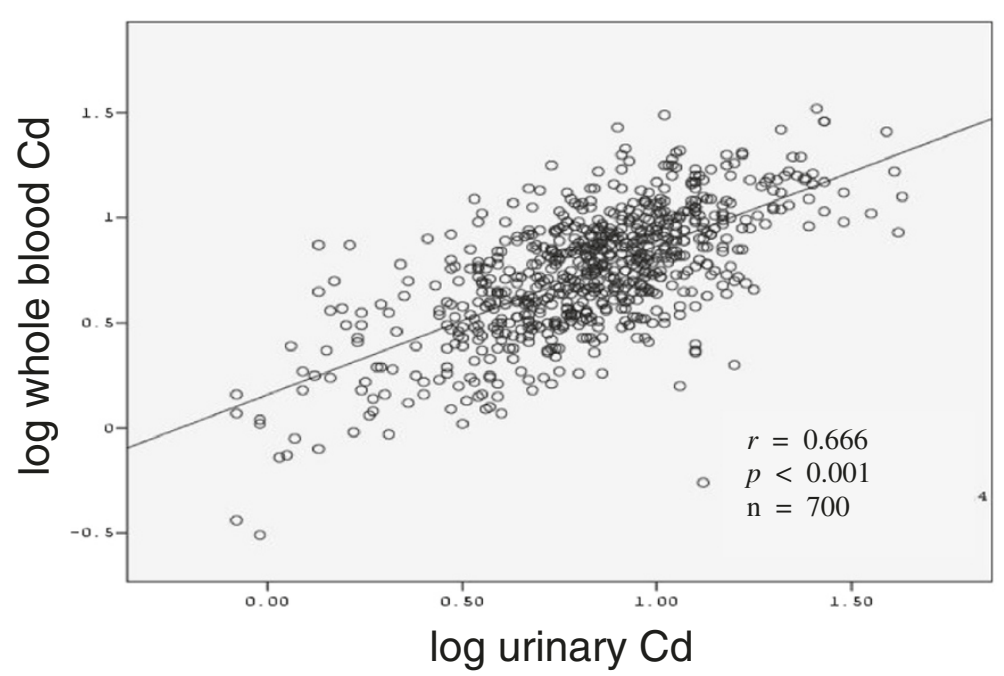

Figure 1 Positive correlation of the cadmium concentrations in urine $(\mu \mathrm{g} \mathrm{Cd} / \mathrm{g} \mathrm{Cr})$ and whole blood $(\mu \mathrm{g} \mathrm{Cd} / \mathrm{L})$ in the inhabitants $(n=700)$ living in cadmium polluted area, Mae Sot district, Tak province (Spearman's rho analysis).

(Table 3). Three renal biomarkers were significantly correlated with $\mathrm{Cd}$ exposure markers after adjusting age and/or smoking. Particularly, urinary KIM-1 was significantly increased $(\mathrm{P}<0.001)$ with increase of blood $\mathrm{Cd}$ compared to the NAG and $\beta 2-\mathrm{MG}$ in men after elimination of influence by age and smoking.

\section{Dose effect and dose response relationships of renal dysfunction and urinary $\mathrm{Cd}$}

When 4 levels of urinary $\mathrm{Cd}$ concentrations were classified, the renal dysfunction biomarkers in this study show significant positive dose effect relationships with urinary Cd (Table 4). Moreover, to confirm the dose response relationships between urinary KIM-1 and urinary Cd, probit regression analysis was performed based on the prevalence rates of KIM-1-uria shown in Table 5. At this time, 95 percentile value of the quantified urinary KIM-1 in the subjects in both genders whose urinary $\mathrm{Cd}<2 \mu \mathrm{g} / \mathrm{g}$ $\mathrm{Cr}$ was used as cutoff level to determine KIM-1-uria. After logit-converting prevalence of KIM-1uria, scatter plots between cadmium (dose) and prevalence rates of KIM1-uria (response) were performed and shown in Figure 3, with probit regression lines of $\mathrm{Y}=2.27 \mathrm{X}-3.24$ for men and $\mathrm{Y}=2.23 \mathrm{X}-3.81$ for women. The regression lines demonstrates good fitness of Fit $X^{2}$ at $14.6(P=0.201)$ for men and $9.05(\mathrm{P}=0.618)$ for women. When factor of age was added into the model, regression lines with good fitness were $\mathrm{Y}=1.28 \mathrm{X}+0.11$ Age $-8.56\left(\mathrm{X}^{2}=7.98, \mathrm{P}=0.631\right)$ for men and $\mathrm{Y}=2.19 \mathrm{X}+0.013$ Age $-4.48\left(\mathrm{X}^{2}=8.95, \mathrm{P}=\right.$ $0.537)$ for women. The estimated threshold value of the urinary Cd which caused KIM-1-uria and Cd concentrations corresponded to $10 \%$ prevalence of KIM-1-uria for the subjects aged 55.5 years old, was $1.3 \mu \mathrm{g} / \mathrm{g} \mathrm{Cr}$ for men and $5.2 \mu \mathrm{g} / \mathrm{g} \mathrm{Cr}$ for women.

\section{Discussion}

Mae Sot district was the first reported case of environmental $\mathrm{Cd}$ in Thailand from zinc mining activities. The Cd contaminated area was estimated to be about 13,200 rais $\left(\times 1,600 \mathrm{~m}^{2}\right)$ of paddy field affecting 12 villages with a total population of 12,075 in 2004 (Data from Tak Provincial Office). Since the residents consumed local rice grown daily, they were at high risk of chronic $\mathrm{Cd}$ toxicity. Health risk assessment and biomarkers monitoring among residents is important to help protect systemic toxicity of $\mathrm{Cd}$ before reaching severity. Among our

Table 2 Cadmium exposure and smoking status of the subjects

\begin{tabular}{|c|c|c|c|c|c|c|}
\hline \multirow{3}{*}{$\begin{array}{l}\text { Smoking status } \\
\text { Never smoked ( } n=232 \text { ) }\end{array}$} & \multicolumn{3}{|c|}{ Blood Cd $(\mu \mathrm{g} / \mathrm{L})$} & \multicolumn{3}{|c|}{ Urinary $\mathrm{Cd}(\mu \mathrm{g} / \mathrm{g} \mathrm{Cr})$} \\
\hline & \multicolumn{3}{|c|}{ Men women total } & \multicolumn{3}{|c|}{ Men women total } \\
\hline & $4.9(2.0)$ & $4.4(2.1)$ & $4.4(2.1)$ & $5.9(2.3)$ & $7.5(3.0)$ & $7.3(3.0)$ \\
\hline Ex-smoker $(n=204)$ & $6.3(2.0)$ & $4.8(2.3)$ & $5.4(2.2)^{* *}$ & $6.5(2.0)$ & $6.4(2.0)$ & $6.5(2.0)$ \\
\hline Occasional smoker $(n=39)$ & $7.1(1.7)$ & $6.8(1.6)^{* *}$ & $6.9(1.6)^{* * *}$ & $7.8(1.9)$ & $7.1(1.7)$ & $7.5(1.8)$ \\
\hline Regular smoker $(\mathrm{n}=225)$ & $7.3(1.8)^{*}$ & $6.7(1.6)^{* * *}$ & $7.0(1.7)^{* * *}$ & $6.1(1.8)$ & $7.5(1.6)$ & $6.6(1.7)$ \\
\hline
\end{tabular}

Cd: cadmium; $\mu \mathrm{g} / \mathrm{L}$ : microgram per liter; $\mu \mathrm{g} / \mathrm{g} \mathrm{Cr}$ : microgram per gram creatinine.

${ }^{*} \mathrm{P}<0.05$; ${ }^{* *} \mathrm{P}<0.01$; ${ }^{* * *} \mathrm{p}<0.001$ compared to never smoked group.

Values of cadmium represent geometrical mean (geometrical standard). 

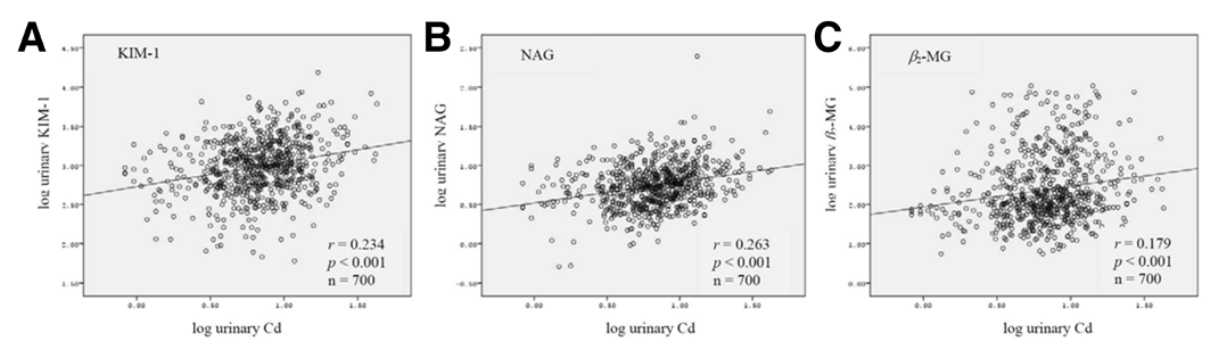

Figure 2 Positive correlations of the urinary cadmium and renal dysfunction biomarkers; A) kidney injury molecule-1 (KIM-1), B) N-acetyl- $\beta$-D-glucosaminidase (NAG) and C) $\beta 2$-microglobulin ( $\beta 2-M G)$, using Spearman's rho analysis.

selected subjects, we found 36 people have urinary $\mathrm{Cd}$ lower than $2 \mu \mathrm{g} / \mathrm{g} \mathrm{Cr}$ and 183 subjects (62 men and 121 women) with very high urinary Cd over $10 \mu \mathrm{g} / \mathrm{g} \mathrm{Cr}$, indicating that the exposure is still going on in some subjects and some but less has reduced. One of the subjects had urinary KIM-1 at the concentration of $15330 \mathrm{pg} / \mathrm{g}$ $\mathrm{Cr}$, suggesting the existence of severe renal tubular injury in Mae Sot residents. This person was later referred for medical checkup and proper healthcare at Mae Sot General Hospital.

Blood and urinary $\mathrm{Cd}$ are useful indicators of $\mathrm{Cd}$ body burden, whereas blood $\mathrm{Cd}$ also reflects $\mathrm{Cd}$ exposure during recent several years (WHO 1992). Men were found to have statistically significant higher blood Cd concentrations than women (Table 2). The results were different from a previous report of Rey et al. (1997) in which there was no difference between gender and blood $\mathrm{Cd}$ concentration was $0.94 \mu \mathrm{g} / \mathrm{L}$ in men and $1.12 \mu \mathrm{g} / \mathrm{l}$ in women. Willer (1992) also reported the concentration of whole blood $\mathrm{Cd}$ at $0.19 \mu \mathrm{g} / \mathrm{L}$. The difference in these studies might have resulted from either high dietary $\mathrm{Cd}$ exposure or smoking consumption. Since smoking is one

Table 3 Relationships between cadmium exposure marker and renal dysfunction markers

\begin{tabular}{|c|c|c|c|c|}
\hline & & KIM-1 & NAG & $\beta 2-M G$ \\
\hline Men & $(N=260)$ & & & \\
\hline \multirow[t]{2}{*}{$\mathrm{U}-\mathrm{Cd}$} & Corr. & $0.295^{* * *}$ & 0.320 *** & 0.182 ** \\
\hline & Partial corr. & $0.289^{* * *}$ & $0.312^{* * *}$ & $0.156 *$ \\
\hline \multirow[t]{2}{*}{$\mathrm{B}-\mathrm{Cd}$} & Corr. & $0.265^{* * *}$ & $0.200^{* *}$ & $0.199 * *$ \\
\hline & Partial corr. & $0.224^{* * *}$ & 0.150 * & $0.132 *$ \\
\hline Women & $(N=440)$ & & & \\
\hline \multirow[t]{2}{*}{$\mathrm{U}-\mathrm{Cd}$} & Corr. & $0.215^{* * *}$ & $0.251 * * *$ & $0.190 * * *$ \\
\hline & Partial corr. & $0.205^{* * *}$ & $0.242 * * *$ & $0.178 * * *$ \\
\hline \multirow[t]{2}{*}{$\mathrm{B}-\mathrm{Cd}$} & Corr. & $0.205^{* * *}$ & $0.165^{* * *}$ & $0.228^{* * *}$ \\
\hline & Partial corr. & $0.161 * *$ & $0.103 *$ & $0.174^{* * *}$ \\
\hline
\end{tabular}

U-Cd: urinary cadmium; B-Cd: whole blood cadmium; N: number of subjects; Corr.: correlation coefficient (Pearson); Partial corr.: partial correlation coefficient after controlling.

by age for U-Cd, by age and smoking habit (yes1, no0).

${ }^{*} \mathrm{p}<0.05 ;{ }^{* *} \mathrm{p}<0.01 ;{ }^{* * *} \mathrm{p}<0.001$. of cadmium exposure source, Cd concentrations in blood and urine with never smoked people showed high $\mathrm{Cd}$ levels over $2 \mu \mathrm{g} / \mathrm{g} \mathrm{Cr}$ and blood Cd was increased accordingly to the smoking status (Table 2), however, urinary $\mathrm{Cd}$ concentrations were not different between non-smokers and smokers. Therefore, correlations of blood $\mathrm{Cd}$ with renal markers were analyzed after adjusting not only age but also smoking status, but correlations of urinary $\mathrm{Cd}$ was computed after adjusting only age.

The critical concentration of $\mathrm{Cd}$ that induced nephropathy has been studied. Because nephropathy was not a clear-cut clinical entity, many biomarkers for early detection of $\mathrm{Cd}$ induced renal dysfunction such as NAG, albumin, $\beta_{2}$-MG, $\alpha_{1}$-MG etc. had been used in several studies (Jung et al. 1993; Jin et al. 2002; Moriguchi et al. 2003; Teeyakasem et al. 2007). In Thai subjects, Teeyakasem et al. (2007) used urinary $\mathrm{Cd}$ as an index of $\mathrm{Cd}$ exposure and used $\beta_{2}$-MG, NAG, total protein, albumin, aminonitrogen, lysozyme and glucose as indicators of $\mathrm{Cd}$ nephrotoxicity. However, another low molecular weight protein, i.e.

Table 4 Dose response relationship of the urinary cadmium (4 levels) and renal dysfunction biomarkers of the subjects

\begin{tabular}{|c|c|c|c|c|}
\hline $\begin{array}{l}\text { Cadmium } \\
(\mu \mathrm{g} / \mathrm{g} \mathrm{Cr})\end{array}$ & $\mathbf{N}$ & $\begin{array}{l}\text { KIM-1 } \\
\text { (pg/g Cr) }\end{array}$ & $\begin{array}{l}\text { NAG } \\
(\mathrm{U} / \mathrm{g} \mathrm{Cr})\end{array}$ & $\begin{array}{l}\beta 2-M G \\
(\mu \mathrm{g} / \mathrm{g} \mathrm{Cr})\end{array}$ \\
\hline \multicolumn{5}{|l|}{ Men } \\
\hline$<2$ & 13 & $513.9(2.2)$ & $4.0(2.2)$ & $137.1(5.0)$ \\
\hline $2-4.99$ & 67 & $686.8(2.2)$ & $4.5(1.8)$ & $266.2(9.4)$ \\
\hline $5-9.99$ & 118 & $863.2(2.2)^{*}$ & $5.0(1.7)$ & $345.0(8.9)$ \\
\hline$\geq 10$ & 62 & $1211.2(2.1)^{* *}$ & $7.5(2.0)^{* *}$ & $721.3(10.5)^{*}$ \\
\hline \multicolumn{5}{|l|}{ Women } \\
\hline$<2$ & 23 & $711.9(2.0)$ & $3.8(2.1)$ & $61.4(3.4)$ \\
\hline $2-4.99$ & 95 & $922.4(2.2)$ & $5.1(1.8)$ & $175.1(5.6)^{*}$ \\
\hline $5-9.99$ & 201 & $1040.9(2.2)$ & $5.5(1.7)^{*}$ & $160.9(5.9)^{*}$ \\
\hline$\geq 10$ & 121 & $1269.4(2.4)^{* *}$ & $7.1(1.9)^{* * *}$ & $294.8(6.7)^{* * *}$ \\
\hline \multicolumn{5}{|c|}{$\begin{array}{l}\text { N: number of subjects; KIM- } 1 \text { : kidney injury molecule- } 1 \text {; NAG: } N \text {-acetyl- } \beta \text {-D- } \\
\text { glucosaminidase; } \beta 2-M G: \beta_{2} \text { microglobulin. } \\
\text { *P }<0.05 ;{ }^{* *} P<0.01 ;{ }^{* *} \mathrm{P}<0.001 \text { : significant different from the subjects group } \\
\text { with cadmium concentrations below } 2 \mu \mathrm{g} / \mathrm{g} C \mathrm{Cr} \text { (Dunnet T test for post hock). } \\
\text { Values of renal markers represent geometrical mean (geometrical } \\
\text { standard deviation). }\end{array}$} \\
\hline
\end{tabular}


Table 5 Prevalence rates of urinary KIM-1 among urinary Cd categories

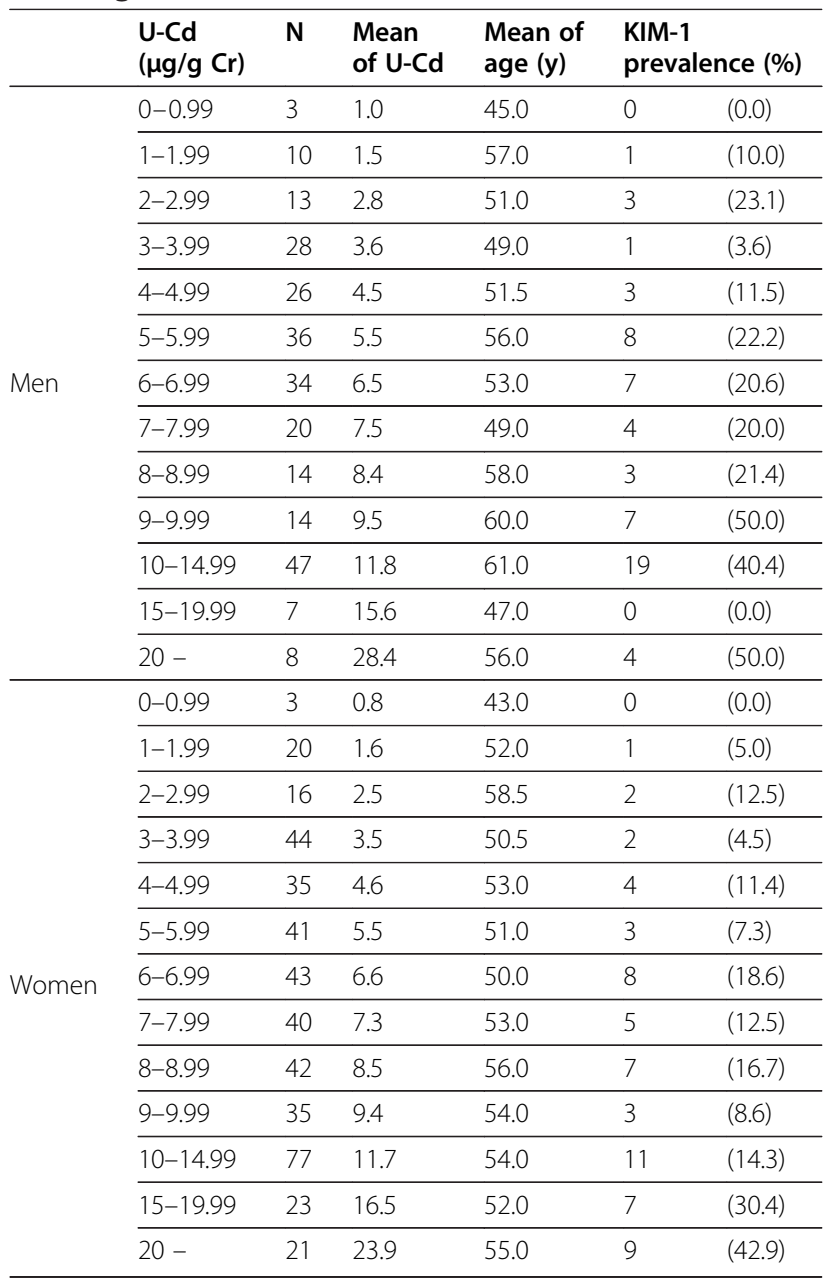

$\mathrm{N}$ : number of subjects, y: years, $\mathrm{U}-\mathrm{Cd}$ : urinary $\mathrm{Cd}$.

Cutoff values for U-KIM-1 = 1,577 $\mu \mathrm{g} / \mathrm{g}$ Cr for men, $2,413 \mu \mathrm{g} / \mathrm{g} \mathrm{Cr}$ for women, which were $95 \%$ tile values of the subjects with U-Cd $<2 \mu \mathrm{g} / \mathrm{g} \mathrm{Cr}$.

kidney injury molecule-1 (KIM-1) had not yet been studied in the urine of high $\mathrm{Cd}$ exposure such as that in the Mae Sot inhabitants. The developed in house-ELISA for quantitating urinary KIM-1 validated in our previous study (Panyamoon et al. 2009) was highly sensitive, with LOD of $33.2 \mathrm{pg} / \mathrm{mL}$ and LOQ of $110.7 \mathrm{pg} / \mathrm{mL}$. There was no urinary sample with KIM-1 concentration lower than the LOQ value. The assay precision in all \% CV was less than $20 \%$ and was accepted as very high precision (FDA 2001). The assay accuracy was also high with approximately 90\% recovery. This result indicated that our developed ELISA technique gave a very high sensitivity and specificity for KIM-1 measurement in urine samples. In addition, KIM-1 in urine was stable even after the urine was frozen and thawed for 4 cycles. The finding was similar to what Han and Bonventre (2004) reported. KIM-1 was also stable for short-term storage at $4^{\circ} \mathrm{C}$ for 5 days. Nowadays, there is limited data of KIM-1. Urinary KIM-1

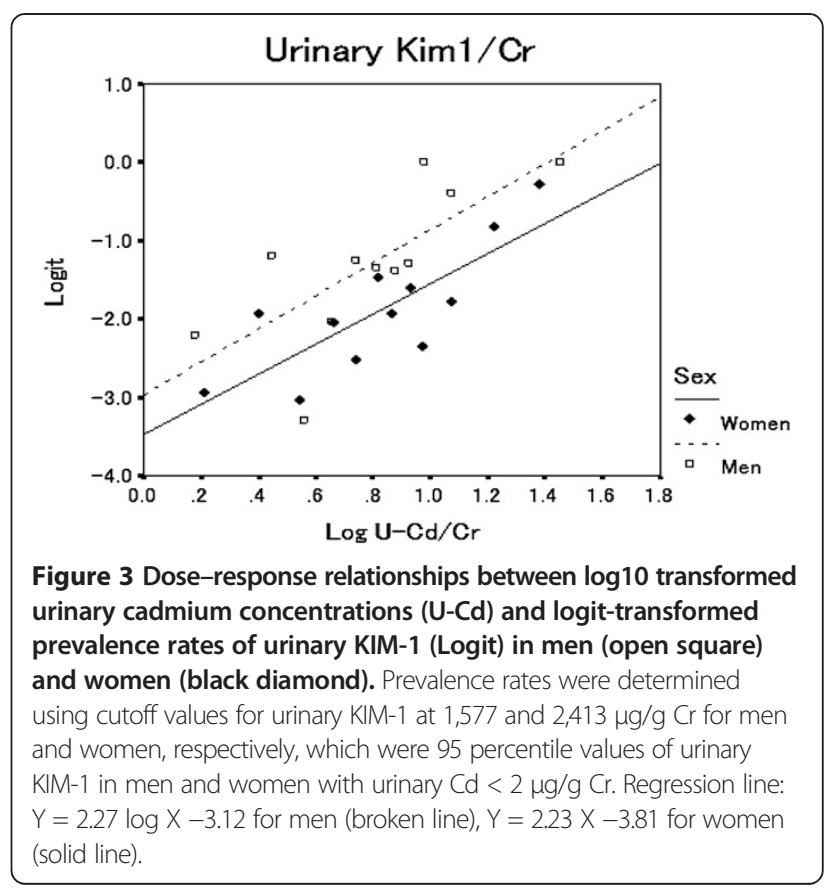

had been mostly used as a biomarker of nephrotoxic injury in animal models (Ichimura et al. 1998; Vaidya et al. 2006; Prozialeck et al. 2009) and only in human patients with renal diseases (Han et al. 2002). This is the first report of KIM-1 as a potential marker on indication of renal dysfunction induced by environmental exposure to cadmium.

Urinary excretion of NAG had been recommended as a sensitive biomarker of $\mathrm{Cd}$ exposure and is more sensitive than $\beta_{2}$-MG (WHO 1992). However, Jung et al. (1993) recommended a combination of NAG and $\alpha_{1}$-MG for early detection of $\mathrm{Cd}$ induced renal injury. Fifty eight men and 123 women in this study had urinary NAG excretion over $8 \mathrm{U} / \mathrm{g}$ Cr suggested proximal tubular damage had occurred. Although the urinary NAG was shown to be the best biomarker that correlated well with urinary $\mathrm{Cd}$, we found that the prevalence rate of NAG-uria was lower than hyper KIM-1-uria. In addition, an increase of NAG level had been reported in variable of conditions such as chronic glomerular disease (Bazzi et al. 2002) and diabetic nephropathy (Ikenaga et al. 1993). The urinary NAG is quantitated by colorimetric assay technique and its activity might be inhibited by endogenous urea (Bondiou et al. 1985), while urinary KIM-1 was measured via antigenantibody reaction; therefore, KIM-1 might be more sensitive than urinary NAG.

In this study, urinary $\beta_{2}$-MG had wide ranges between $5-107,883 \mu \mathrm{g} / \mathrm{g}$ Cr. Two women had $\beta_{2}$-MG concentrations over $100,000 \mu \mathrm{g} / \mathrm{g} \mathrm{Cr}$, suggesting severe renal tubular dysfunction. However, an increase of urinary $\beta_{2}$-MG excretion had been also found in other diseases, cardiac surgery (Dehne et al. 1995) and renal transplantation 
(Schaub et al. 2005). In addition, urinary $\beta_{2}$-MG likes to be degraded rapidly at room temperature and in the urine with $\mathrm{pH}$ less than 6.0. Thus, it is reasonable to conclude that urinary KIM- 1 is a better biomarker for indicating renal tubular dysfunction than $\beta_{2}$-MG.

In the present study, clear dose-response relationship between urinary KIM-1 and urinary Cd was shown, and threshold values of KIM-1-uria in both genders were lower than those of urinary NAG and $\beta_{2}$-MG. These results also confirm urinary KIM-1 is useful marker to detect urinary tubular dysfunction at early stage. However, in this analysis, 95 percentile values of KIM-1 of men and women with urinary $\mathrm{Cd}<2 \mu \mathrm{g} / \mathrm{g} \mathrm{Cr}$ were used for cut-off values to calculate of prevalence of KIM-1-uria. This is a big limitation of this analysis, because we have no controls and residents with lower exposure needed to use as controls. In future, we select suitable controls for Mae Sot residents and measure KIM-1 to detect reference value for Thai population. Then, we are going to use this marker to detect early sign of renal effect in $\mathrm{Cd}$ exposed subjects, particularly young people with low $\mathrm{Cd}$ body burden.

\section{Competing interests}

The authors declare that they have no conflicts of interests.

\section{Authors' contributions}

WR designed the study and drafted the manuscript. AP carried out KIM-1 measurement, and RN participated in cadmium measurement. KN and WS conducted epidemiological survey and created data base. MN analyzed data and helped to write the manuscript particularly discuss part. All authors read and approved the final manuscript.

\section{Acknowledgements}

Thanks to all of the participants who live in Mae Sot district, Tak province for their kind cooperation. We thank the staffs of Mae Sot General Hospital, especially Ms. Pranee Mahasakpan for their help on the epidemiological survey. Our appreciation goes to Dr. Bruce G. Weniger for his valuable comments on manuscript writing. The work was supported by the Faculty of Medicine Endowment Fund, Faculty of Medicine, Chiang Mai University and Kanazawa Medical University, Uchinada, Ishikawa, Japan.

\section{Author details}

${ }^{1}$ Division of Toxicology, Faculty of Medicine, Chiang Mai University, Chiang Mai, Thailand. ${ }^{2}$ School of Health Science, Mae Fah Luang University, Chiang Rai, Thailand. ${ }^{3}$ Department of Social and Environmental Health, Kanazawa Medical University, Ishikawa, Japan. ${ }^{4}$ Department of Social Medicine, Mae Sot General Hospital, Tak Province, Thailand. ${ }^{5}$ Department of Public Health, Kanazawa Medical University, Uchinada, Ishikawa, Japan.

Received: 6 September 2013 Accepted: 9 October 2013 Published: 17 October 2013

\section{References}

Aoshima K, Iwata K, Kasuya M (1988) Environmental exposure to cadmium and effects of human health. Part2 bone and mineral metabolism in inhabitants of the cadmium-polluted Jinzu river basin in Toyama prefecture. Jpn J Hyg 43:864-871

Bazzi C, Petrini C, Rizza V, Arrigo G, Napodano P, Paparella M (2002) Urinary $\mathrm{N}$-acetyl-beta-glucosaminidase excretion is a marker of tubular cell dysfunction and a predictor of outcome in primary glomerulonephritis. Nephrol Dial Transplant 17:1890-1896
Bondiou M, Bourbouze R, Bernard M, Percheron F, Perez-Gonzalez N, Cabezas J (1985) Inhibition of A and B N-acetyl- $\beta$-d-glucosaminidase urinary isoenzymes by urea. Clin Chim Acta 149:67-73

Bonventre JV (2009) Kidney injury molecule-1 (KIM-1): a urinary biomarker and much more. Nephrol Dial Transplant 24:3265-3268

Dehne MG, Boldt J, Heise D, Sablotzki A, Hempelmann G (1995) Tamm-Horsfall-protein, a 1- and $\beta$ 2-microglobulin as micromolecular markers of renal function in cardiac surgery. Anaesthesist 44:545-551

DeSilva B, Smith W, Weiner R, Kelley M, Smolec J, Lee B, Khan M, Tacey R, Hill H, Celmiker A (2003) Recommendations for the bioanalytical method validation of ligand-binding assays to support pharmacokinetic assessments of macromolecules. Pharm Res 20:1885-1900

FDA (2001) Guidance for industry bioanalytical method validation. http://www. fda.gov/downloads/Drugs/GuidanceComplianceRugulatorylnformation/ Guidances/UCM070107.pdf.html. Accessed 1 November 2009

Ferguson MA, Vaidya VS, Bonventre JV (2008) Biomarkers of nephrotoxic acute kidney injury. Toxicology 245:182-193

Friberg L (1984) Cadmium and the kidney. Environ Health Perspect 54:1-11

Han WK, Bonventre JV (2004) Biologic markers for the early detection of acute kidney injury. Curr Opin Crit Care 10:476-482

Han WK, Bailly V, Abichandani R, THADHANI R, Bonventre JV (2002) Kidney injury molecule-1 (KIM-1): A novel biomarker for human renal proximal tubule injury. Kidney Int 62:237-244

Hoffman D, Adler M, Vaidya VS et al (2010) Performance of novel kidney biomarkers in preclinical toxicity studies. Toxicol Sci 116:8-22

Honda R, Swaddiwudhipong W, Nishijo M, Mahasakpan P, Teeyakasem W, Ruangyuttikarn W, Satarug S, Padungtod C, Nakagawa H (2010) Cadmium induced renal dysfunction among residents of rice farming area downstream from a zinc-mineralized belt in Thailand. Toxicol Lett 198:26-32

Ichimura T, Joseph V, Bonventre JV, Ronique Bailly V, Wei H, Hession CA, Cate RL, Sanicola M (1998) Kidney injury molecule-1 (KIM-1), a putative epithelial cell adhesion molecule containing a novel immunoglobulin domain, is up-regulated in renal cells after injury. J Biol Chem 273:4135-4142

Ichimura T, Hung CC, Yang SA, Stevens JL, Bonventre JV (2004) Kidney injury molecule-1: a tissue and urinary biomarker for nephrotoxicant-induced renal injury. Am J Physiol Renal Physiol 286:F552-F563

Ikenaga H, Suzuki H, Ishii N, Itoh H, Saruta T (1993) Enzymuria in non-insulin-dependent diabetic patients: Signs of tubular cell dysfunction. Clin Sci 84:469-475

Jarup L, Berglund M, Elinder CG, Nordberg G, Vahter M (1998) Health effects of cadmium exposure - a review of the literature and a risk estimate. Scand J Work Environ Health 24(Suppl 1):1-51

Jin T, Nordberg M, Dumont X, Bernard A, Ye T (2002) Cadmium biomonitoring and renal dysfunction among a population environmentally exposure to cadmium from smelting in China. Biometals 15:397-410

Jung K, Pergande M, Graubaum HJ, Fels LM, Endl U, Stolte H (1993) Urine proteins and exzymes as early indicators of renal dysfunction in chronic exposure to cadmium. Clin Chem 39:757-765

Lauwerys RR, Bernard A, Roels HA, Buchet JP, Viau C (1984) Characterization of cadmium proteinuria in man and rat. Environ. Health Perspect 54:147-152

Moriguchi J, Ezaki T, Tsukahara T, Furuki K, Fukui Y, Okamoto S et al (2003) Comparative evaluation of four urinary tubular dysfunction markers, with special references to the effects of aging and correction for creatinine concentration. Toxicol Lett 143:279-290

Nambunmee K, Honda R, Nishijo M, Swaddiwudhipong W, Nakagawa H, Ruangyuttikarn W (2010) Bone resorption acceleration and calcium reabsorption impairment in Thai population with high cadmium exposure. Toxicol Mech Methods 20:7-13

Nambunmee K, Honda R, Nishijo M, Swaddiwudhipong W, Nakagawa H, Ruangyuttikarn W (2011) Bone cadmium exposure in Mae Sot population is associated with high anemia prevalence. Thai J Toxicol 26:29-43

Nogawa K, Tsuritani I, Honda R, Yamada Y, Ishizaki M (1987) Mechanism for bone disease found in inhabitants environmentally exposed to cadmium: decreased serum 1a, 25-dihydroxyvitamin D level. Int Arch Occup Environ Health 59:21-30

Panyamoon A, Nambunmee K, Nishijo M, Swaddiwudhipong W, Ruangyuttikarn W (2009) Detection of urinary kidney injury molecule 1 in a chronic cadmium exposed population, MaeSot district, Tak province. Tai J Toxicol 24:72-80

Pennemans V, De Winter LM, Munters E, Nawrot TS, Kerkhove EV, Rigo JM, Reynders C, Dewitte H, Carleer R, Penders J, Swennen Q (2011) The association between urinary kidney injury molecule 1 and urinary cadmium in elderly during long-term, low-dose cadmium exposure: a pilot study. Environ Health 10:77. doi:10.1186/1476-069X-10-77 

Expression of kidney injury molecule-1 (Kim-1) in relation to necrosis and apoptosis during the early stages of $\mathrm{Cd}$-induced proximal tubule injury. Toxicol Appl Pharm 238:306-314

Rey M, Turcotte F, Lapoinate C, Dewailly E (1997) High blood cadmium levels are not associated with consumption of traditional food among the inuit of Nunavik. J Toxicol Environ Health 51:5-14

Simmons RW, Pongsakul P, Saiyasitpanich D, Klinphoklap S (2005) Elevated levels of cadmium and zinc in paddy soils and elevated levels of cadmium in rice grain downstream of a zinc mineralized area in Thailand: implication for public health. Environ. Geochem Health 27:501-511

Schaub S, Wilkins JA, Antonovici M, Krokhin O, Weiler T, Rush D, Nickerson P (2005) Proteomic-based identification of cleaved urinary $\beta 2$-microglobulin as a potential marker for acute tubular injury in renal allografts. Am J Transplant 5:729-738

Swaddiwudhipong W, Limpatanachote P, Mahasakpan P, Somyos K, Padungtod C (2007) Cadmium-exposed population in Mae Sot district, Tak province: 1. Prevalence of high urinary cadmium levels in the adults. J Med Assoc Thai 90:143-148

Swaddiwudhipong W, Mahasakpan P, Limpatanachote P, Krintratun S (2010) Correlations of urinary cadmium with hypertension and diabetes in persons living in cadmium-contaminated villages in northwestern Thailand: A population study. Environ Res 110:612-616

Swaddiwudhipong W, Limpatanachote P, Mahasakpan P, Krintratun S, Punta B, Funkhiew T (2012) Progress in cadmium-related health effects in persons with high environmental exposure in northwestern Thailand: A five-year follow-up. Environ Res 111:579-583

Teeyakasem W, Nishijo M, Honda R, Satarug S, Swaddiwudhipong W, Ruangyuttikarn W (2007) Monitoring of cadmium toxicity in a Thai population with high-level environmental exposure. Toxicol Lett 169:185-195

Vaidya VS, Ramirez V, Ichimura T, Bobadilla NA, Bonventre JV (2006) Urinary kidney injury molecule-1: a sensitive quantitative biomarker for early detection of kidney tubular injury. Am J Physiol Renal Physiol 290:F517-F529

Vaidya VS, Ferguson MA, Bonventre JV (2008) Biomarkers of acute kidney injury. Annu Rev Pharmacol Toxicol 48:463-493

Van Timmeren MM, van den Heuvel MC, Bailly V, Bakker SJL, van Gour H, Stegeman CA (2007) Tubular kidney injury molecule-1 in human renal disease. J Pathol 212:209-217

Willer S, Attewell R, Bensryd I (1992) Exposure to environmental tobacco smoke in the household and urinary cotinine excretion, heavy metals retention and lung function. Arch Environ Health 47:357-363

WHO (1992) Cadmium. Environmental Health Criteria Document 134, IPCS. WHO, Geneva

doi:10.1186/2193-1801-2-533

Cite this article as: Ruangyuttikarn et al:: Use of the kidney injury molecule-1 as a biomarker for early detection of renal tubular dysfunction in a population chronically exposed to cadmium in the environment. SpringerPlus 2013 2:533.

\section{Submit your manuscript to a SpringerOpen ${ }^{\circ}$ journal and benefit from:}

- Convenient online submission

- Rigorous peer review

- Immediate publication on acceptance

- Open access: articles freely available online

- High visibility within the field

- Retaining the copyright to your article

Submit your next manuscript at $\gg$ springeropen.com 